\title{
EFFECT OF BACTERIA PROPORTION ON THE FERMENTATION OF GOAT YOGHURT WITH PROBIOTIC CULTURE
}

\author{
Guowei Shu ${ }^{1 凶}$, Shuai Wang ${ }^{1}$, Zikun Chen ${ }^{2}$, He Chen ${ }^{1}$, Changfeng Wang ${ }^{1}$, Yaning $\mathrm{Ma}^{3}$ \\ ${ }^{1}$ School of Food and Biological Engineering, Shaanxi University of Science and Technology \\ Xi'an, 710021, China \\ ${ }^{2}$ Xinxiang Institute for Food and Drug Control, Henan Province \\ Xinxiang, 453000, China \\ ${ }^{3}$ Shangqiu Entry-Exit Inspection and Quarantine Bureau, Henan Province \\ Shangqiu, 476000, China
}

\begin{abstract}
Background. Goat milk production in Shaanxi province is dominant in China, but the product is mainly infant formula and adult milk powder; product homogeneity is serious and has no goat yoghurt with probiotic culture.

Methods. The effect of bacteria proportion (1:3:1, 1:2:1, 1:1:1, 2:1:1, 3:1:1) on $\mathrm{pH}$, acidity, and viable counts and sensory evaluation of goat milk fermented by probiotics including L. acidophilus, B. bifidum or L. casei besides, S. thermophilus and L. bulgaricus for developing AB-goat yoghurt and BC-goat yoghurt was investigated.

Results. The optimum bacteria proportion of L. acidophilus : B. bifidum : S. thermophilus and L. bulgaricus for AB-goat yoghurt and B. bifidum : L. casei : S. thermophilus and L. bulgaricus for BC-goat yoghurt were both 2:1:1. The $\mathrm{pH}$, acidity, the viable counts of L. acidophilus and B. bifidum, the total viable counts were respectively $4.60,7.73(\mathrm{~g} / \mathrm{L}), 3.50 \times 10^{7} \mathrm{cfu} / \mathrm{mL}, 3.40 \times 10^{7} \mathrm{cfu} / \mathrm{mL}$ and $2.30 \times 10^{9} \mathrm{cfu} / \mathrm{mL}$ in AB-goat yoghurt. The $\mathrm{pH}$, acidity, the viable counts of B. bifidum and $L$. casei, the total viable counts were respectively 4.61, $8.16(\mathrm{~g} / \mathrm{L}), 7.60 \times 10^{7} \mathrm{cfu} / \mathrm{mL}, 5.60 \times 10^{7} \mathrm{cfu} / \mathrm{mL}$ and $2.04 \times 10^{9} \mathrm{cfu} / \mathrm{mL}$ in BC-goat yoghurt.

Conclusion. The bacteria proportion had a significant effect on fermentation of AB- and BC-goat yoghurt, the results are beneficial for developing $\mathrm{AB}$-goat yoghurt and $\mathrm{BC}$-goat yoghurt.
\end{abstract}

Key words: goat milk, bacteria proportion, L. acidophilus, B. bifidum, L. casei, yoghurt

\section{INTRODUCTION}

Milk products from goat, such as yoghurt and cheese, are becoming increasingly popular in developed countries as substitutes for cow milk products for those who have allergies to cow milk (Haenlein, 2004; Park, 1994). Goat milk production in Shaanxi province amounts to a total of 650,000 tons in 2014 , but the product is mainly infant formula and adult milk powder; product homogeneity is serious and has no goat yoghurt.
Yoghurt that contains probiotics such as L. acidophilus, B. bifidum and L. casei is also becoming popular because probiotics can provide various health benefits such as prevention of gastrointestinal disorders, diarrhea and colon cancer, and alleviating lactose intolerance and improving immunity (Kailasapathy and Chin, 2000; Krasaekoopt et al., 2003; Rolfe, 2000; Singh et al., 2011). Posecion et al. (2005) established 
process conditions suitable for a small-scale goat milk yoghurt and examined the physicochemical properties and organoleptic acceptability of the resultant product. Drinkable yoghurts made with normal and probiotic cultures were evaluated for their sensory characteristics (Uysal-Pala et al., 2006). Quality characteristics of yoghurt from goat milk supplemented with aronia juice and blueberry juice was investigated (Boycheva et al., 2011). Mutlu and Akin (2007) researched effects of cysteine and different incubation temperatures on the microflora, chemical composition and sensory characteristics of bio-yoghurt made from goat's milk. Farnsworth et al. (2006) investigated the effects of transglutaminase treatment on functional properties and probiotic culture survivability of goat milk yoghurt, but the bacteria proportion on goat milk fermented by probiotic culture was not studied.

In our previous study, the process of fermentation set-style type goat yoghurts was optimized by $S$. thermophilus and L. bulgaricus (Chen et al., 2010), the effect of inoculum and temperature on the fermentation of goat yoghurt by L. bulgaricus and S. thermophilus (Shu et al., 2014) was investigated, the effect of the total inoculum size containing $L$. acidophilus or L. casei on the fermentation of goat milk was studied on the basis of S. thermophilus and L. bulgaricus as starter cultures (Chen et al., 2015). The purpose of the present work was to study the effect of bacteria proportion on goat milk fermented by probiotics including $L$. acidophilus, B. bifidum or $L$. casei besides, S. thermophilus and L. bulgaricus for developing goat yoghurt containing L. acidophilus and B. bifidum (AB-goat yoghurt) and goat yoghurt containing B. bifidum and $L$. casei (BC-goat yoghurt).

\section{MATERIAL AND METHOD}

\section{Materials and reagents}

Fresh goat milk mainly composed of fat $(3.75 \mathrm{~g} / 100 \mathrm{~g})$, lactose $(4.13 \mathrm{~g} / 100 \mathrm{~g})$, protein $(3.42 \mathrm{~g} / 100 \mathrm{~g})$, ash $(0.78 \mathrm{~g} / 100 \mathrm{~g})$ and total solids $(12.08 \mathrm{~g} / 100 \mathrm{~g})$ was purchased from local farmers (Xi' an Weiyang, China). All chemicals used were of analytical grade unless otherwise specified.

\section{Microorganism}

L. acidophilus (LA), Bifidobacterium bifidum (BB), L. casei (LC), S. thermophilus (ST) and L. bulgaricus
(LB) were obtained from School of Food and Biological Engineering, Shaanxi University of Science and Technology. They were inoculated three successive times with MRS (for L. acidophilus, B. bifidum, $L$. casei and L. bulgaricus) and M17 (for S. thermophilus) broth (Hopebio, Qindao, China) in order to obtain fresh culture. The activated LA, BB or LC was inoculated into sterilized goat milk at $5 \%$ inoculum size, mixed and cultivated at $37^{\circ} \mathrm{C}$ until coagulation, respectively. The activated $S$. thermophilus and $L$. bulgaricus were inoculated into sterilized goat milk at 5\% inoculum size with $1: 1$ ratio, mixed and cultivated in the incubators until coagulation; they would be used for the production of $\mathrm{AB}$ or $\mathrm{BC}$-goat yoghurt.

\section{Preparation of probiotic goat yoghurts}

Goat milk was heated to $90^{\circ} \mathrm{C}$ for 10 minutes, cooled to $45^{\circ} \mathrm{C}$, and then was divided into equal portions in order to prepare $\mathrm{AB}$-goat yoghurt BC-goat yoghurt, the bacteria proportion (v/v) of L. acidophilus, B. bifidum, $S$. thermophilus and L. bulgaricus for AB-goat yoghurt were $1: 3: 1,1: 2: 1,1: 1: 1,2: 1: 1,3: 1: 1$, the bacteria proportion (v/v) of B. bifidum, L. casei, S. thermophilus and $L$. bulgaricus $\mathrm{BC}$-goat yoghurt was the same as AB-goat yoghurt. The mixed liquid starter cultures of different bacteria proportion were inoculated into goat milk at 5\% total inoculum size mentioned above, then fermented at $39^{\circ} \mathrm{C}$ constant temperature. The acidity, $\mathrm{pH}$ value, viable counts of $L$. acidophilus, B. bifidum or $L$. case $i$, total viable bacteria were determined every other $1.5 \mathrm{~h}$, then given a sensory evaluation after $12 \mathrm{~h}$ in cold storage so as to study the influence of bacteria proportion on the fermentation of goat yoghurt. All samples were carried out by triplicate, each sample was measured three times and the results are the average of three samples.

\section{Analysis methods}

Plate coating method was used to determinate the viable counts, the total viable counts were determinate by modified Tomato Juice medium, determination of L. acidophilus or $L$. casein by MRS agar containing $0.06 \%$ bile salt and determination of B. bifidum by MRS agar containing $0.10 \% \mathrm{LiCl}$ (Chen et al., 2011; Shu et al., 2011). The $\mathrm{pH}$ of culture media was directly determined through a $\mathrm{pH}-$ meter (pHS-3c) at the room temperature, acidity was determined by titration with 
Shu, G., Wang, S., Chen, Z., Chen, H., Wang, C., Ma, Y. (2015). Effect of bacteria proportion on the fermentation of goat yoghurt with probiotic culture. Acta Sci. Pol. Technol. Aliment., 14(4), 407-414. DOI: 10.17306/J.AFS.2015.4.40

$0.1 \mathrm{~N} \mathrm{NaOH}$ and expressed in lactic acid content $(\mathrm{g} / \mathrm{L})$. The samples were organoleptically assessed by five panelists, tasted and described the texture of the product: colour, texture, taste, smell, who were trained on the basis of normal sensory acuity and consistency.

\section{RESULTS AND DISCUSSION}

\section{Effect of bacteria proportion on the fermentation of AB-goat yoghurt}

The effect of bacteria proportion on the fermentation of AB-goat yoghurt was shown in Figure 1 and Table 1.

Figure 1a showed viable counts of L. acidophilus in all AB-goat yoghurt samples first increased within $4.5 \mathrm{~h}$, and then decreased between $4.5 \mathrm{~h}$ and $6.0 \mathrm{~h}$ at different bacteria proportion. The viable counts of L. acidophilus first increased from $1.83 \times 10^{7} \mathrm{cfu} / \mathrm{ml}$ at $1.5 \mathrm{~h}$ to $3.46 \times 10^{7} \mathrm{cfu} / \mathrm{ml}$ at $4.5 \mathrm{~h}$, and then decreased to $2.70 \times 10^{7} \mathrm{cfu} / \mathrm{ml}$ at $6 \mathrm{~h}$ when the bacteria proportion was $1: 3: 1$. The viable counts of $L$. acidophilus first increased from $1.50 \times 10^{7} \mathrm{cfu} / \mathrm{ml}$ at $1.5 \mathrm{~h}$ to $3.40 \times 10^{7} \mathrm{cfu} / \mathrm{ml}$ at $4.5 \mathrm{~h}$, and then decreased to $2.84 \times 10^{7} \mathrm{cfu} / \mathrm{ml}$ at $6 \mathrm{~h}$ when the bacteria proportion was $1: 2: 1$. The viable counts of $L$. acidophilus first increased from $1.33 \times 10^{7} \mathrm{cfu} / \mathrm{ml}$ at $1.5 \mathrm{~h}$ to $3.39 \times 10^{7}$ $\mathrm{cfu} / \mathrm{ml}$ at $4.5 \mathrm{~h}$, and then decreased to $2.32 \times 10^{7} \mathrm{cfu} / \mathrm{ml}$ at $6 \mathrm{~h}$ when the bacteria proportion was 1:1:1. The viable counts of $L$. acidophilus first increased from $1.43 \times 10^{7} \mathrm{cfu} / \mathrm{ml}$ at $1.5 \mathrm{~h}$ to $3.50 \times 10^{7} \mathrm{cfu} / \mathrm{ml}$ at $4.5 \mathrm{~h}$, and then decreased to $2.70 \times 10^{7} \mathrm{cfu} / \mathrm{ml}$ at $6 \mathrm{~h}$ when the bacteria proportion was $2: 1: 1$. The viable counts of L. acidophilus first increased from $1.07 \times 10^{7} \mathrm{cfu} / \mathrm{ml}$ at $1.5 \mathrm{~h}$ to $3.80 \times 10^{7} \mathrm{cfu} / \mathrm{ml}$ at $4.5 \mathrm{~h}$, and then decreased to $3.60 \times 10^{7} \mathrm{cfu} / \mathrm{ml}$ at $6 \mathrm{~h}$ when the bacteria proportion was $3: 1: 1$. Among them, the viable counts of $L$. acidophilus at 3:1:1 bacteria proportion reached the maximum $\left(3.60 \times 10^{7} \mathrm{cfu} / \mathrm{mL}\right)$, the viable counts at $1: 1: 1$ bacteria proportion was the lowest $\left(3.39 \times 10^{7} \mathrm{cfu} / \mathrm{ml}\right)$ at $4.5 \mathrm{~h}$.

Figure $1 \mathrm{~b}$ showed the change of viable counts of B. bifidum in all AB-goat yoghurt samples was the same as $L$. acidophilus. The viable counts of $B$. bifidum first increased quickly within $3 \mathrm{~h}$, then increased slowly to maximum between 3.0 and $4.5 \mathrm{~h}$, then decreased between 4.5 and $6.0 \mathrm{~h}$. Among them, the viable counts of $B$. bifidum at 2:1:1 bacteria proportion reached the maximum $\left(3.40 \times 10^{7} \mathrm{cfu} / \mathrm{mL}\right)$, the viable counts of $B$. bifidum at 1:3:1 bacteria proportion was the lowest $\left(2.11 \times 10^{7} \mathrm{cfu} / \mathrm{ml}\right)$.

Figure 1c showed that the total viable counts in AB-goat yoghurt were all first increased then decreased as L. acidophilus or B. bifidum with time increasing. Among them, the total viable counts at 3:1:1 bacteria proportion reached the maximum $\left(2.50 \times 10^{9}\right.$ $\mathrm{cfu} / \mathrm{mL})$ followed at $3: 1: 1\left(2.30 \times 10^{9} \mathrm{cfu} / \mathrm{mL}\right)$, the total viable counts at $1: 1: 1$ bacteria proportion was the minimum $\left(1.79 \times 10^{9} \mathrm{cfu} / \mathrm{mL}\right)$. From Figure $1 \mathrm{~d}$ and $1 \mathrm{e}$, $\mathrm{pH}$ in all AB-goat yoghurt decreased rapidly within $4.5 \mathrm{~h}$, then began to slow down, while the variation trend of acidity in all AB-goat yoghurt was opposite to $\mathrm{pH}$. The acidity and $\mathrm{pH}$ at 3:1:1, 2:1:1 bacteria proportion was $7.84(\mathrm{~g} / \mathrm{L}), 7.73(\mathrm{~g} / \mathrm{L})$ and $4.59,4.60$ for $4.5 \mathrm{~h}$, respectively.

Table 1. The sensory evaluation of AB-goat yoghurt fermented by different bacteria proportion

\begin{tabular}{cccccc}
\hline $\begin{array}{c}\text { Bacteria pro- } \\
\text { portion of } \\
\text { LA:BB:LB+ST }\end{array}$ & Colour & Smell & Taste & Texture & $\begin{array}{c}\text { Comprehensive } \\
\text { evaluation }\end{array}$ \\
\hline $1: 3: 1$ & 0.8 & 1.76 & 1.89 & 2.36 & 6.81 \\
$1: 2: 1$ & 0.8 & 1.72 & 2.00 & 2.39 & 6.91 \\
$1: 1: 1$ & 0.8 & 1.84 & 2.03 & 2.39 & 7.06 \\
$2: 1: 1$ & 0.8 & 1.86 & 2.24 & 2.40 & 7.30 \\
$3: 1: 1$ & 0.8 & 1.76 & 2.00 & 2.37 & 6.93 \\
\hline
\end{tabular}


Shu, G., Wang, S., Chen, Z., Chen, H., Wang, C., Ma, Y. (2015). Effect of bacteria proportion on the fermentation of goat yoghurt with probiotic culture. Acta Sci. Pol. Technol. Aliment., 14(4), 407-414. DOI: 10.17306/J.AFS.2015.4.40
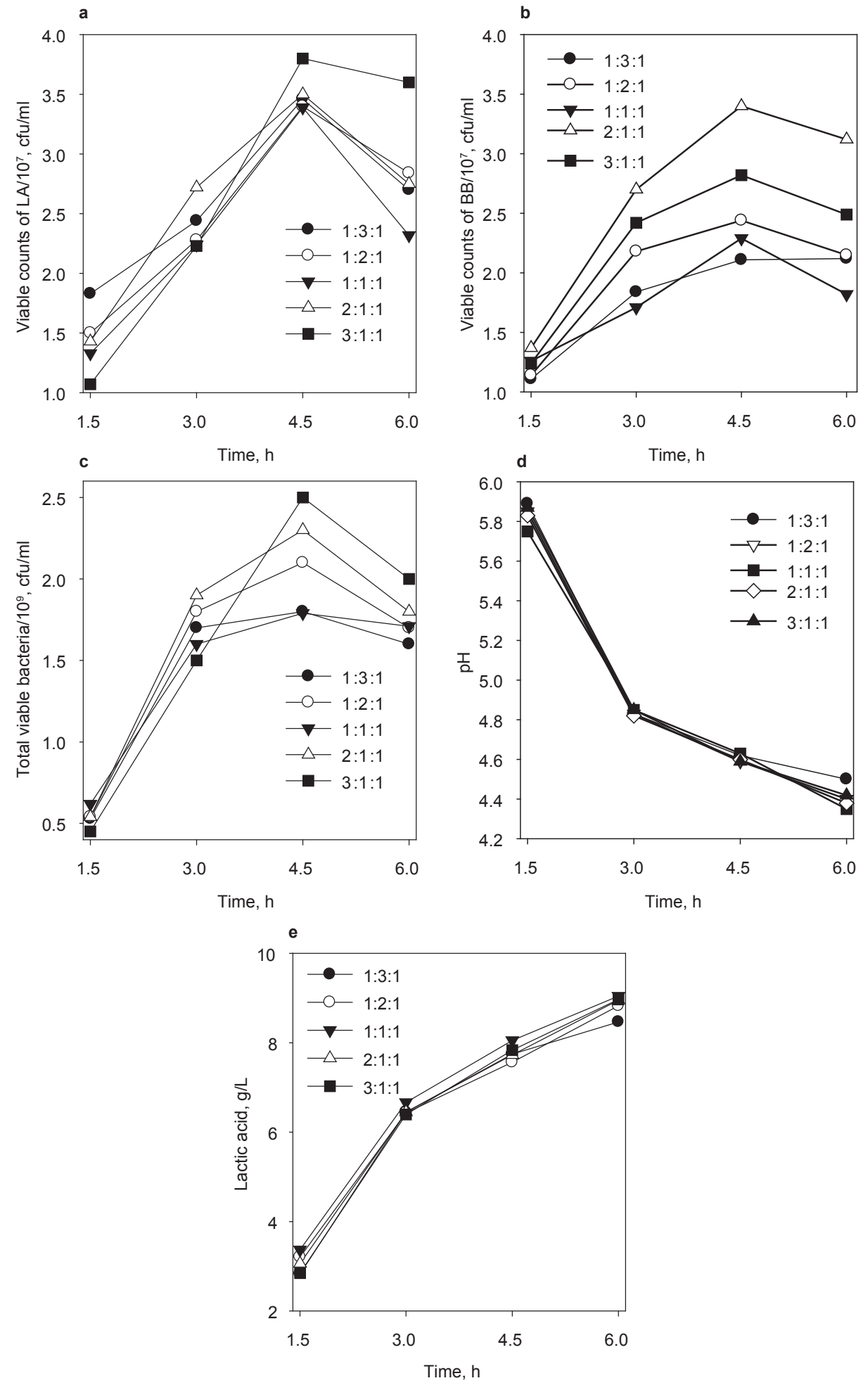

Fig. 1. Effect of bacteria proportion on viable counts of L. acidophilus and B. bifidum, total viable bacteria, $\mathrm{pH}$ and acidity in $\mathrm{AB}$-goat yoghurt 
Shu, G., Wang, S., Chen, Z., Chen, H., Wang, C., Ma, Y. (2015). Effect of bacteria proportion on the fermentation of goat yoghurt with probiotic culture. Acta Sci. Pol. Technol. Aliment., 14(4), 407-414. DOI: 10.17306/J.AFS.2015.4.40

Table 1 showed the bacteria proportion had no obvious influence on the colour, texture of goat yoghurt, however, it had a significant effect on goat yoghurt odour and taste. Among them, the sour of goat yoghurt taste a little pale and has slight goaty flavor at 1:1:1, 1:2:1, 1:3:1, 3:1:1 bacteria proportion. The sweet and sour of goat yoghurt was moderate, goaty flavour and comprehensive evaluation was better in 2:1:1 bacteria proportion.

The changes of the total viable counts, L. acidophilus and B. bifidum in AB-goat yoghurt were all first increased then decreased, the $\mathrm{pH}$ decreased and acidity increased during the fermentation process, which affected the growth and survival of probiotics in goat yoghurt. According to sensory evaluation, viable counts, acidity and $\mathrm{pH}$ of goat milk fermented by probiotics, the optimum bacteria proportion $L$. acidophilus : B. bifidum : S. thermophilus and L. bulgaricus for AB-goat yoghurt was 2:1:1.

\section{Effect of bacteria proportion on the fermentation of BC-goat yoghurt}

The effect of bacteria proportion on the fermentation of BC-goat yoghurt was shown in Figure 2 and Table 2.

Figure 2a showed B. bifidum grew faster in BC-goat yoghurt at 2:1:1 and 3:1:1 than other bacteria proportion. The viable counts of $B$. bifidum increased at 1:3:1 bacteria proportion, first increased within $4.5 \mathrm{~h}$, and then decreased between $4.5 \mathrm{~h}$ and $6.0 \mathrm{~h}$ at 1:2:1, 2:1:1 and 3:1:1 bacteria proportion, first increased within $3.0 \mathrm{~h}$, and then decreased between $3.0 \mathrm{~h}$ and $6.0 \mathrm{~h}$ at
1:1:1 bacteria proportion with time increasing. The viable counts of B. bifidum in BC-goat yoghurt samples increased from $1.10 \times 10^{7} \mathrm{cfu} / \mathrm{ml}$ at $1.5 \mathrm{~h}$ to $3.20 \times 10^{7}$ $\mathrm{cfu} / \mathrm{ml}$ at $6.0 \mathrm{~h}$ at $1: 3: 1$ bacteria proportion, first increased from $1.40 \times 10^{7} \mathrm{cfu} / \mathrm{ml}$ at $1.5 \mathrm{~h}$ to $3.41 \times 10^{7}$ $\mathrm{cfu} / \mathrm{ml}$ at $4.5 \mathrm{~h}$, and then decreased to $2.52 \times 10^{7} \mathrm{cfu} / \mathrm{ml}$ at $6 \mathrm{~h}$ when the bacteria proportion was $1: 2: 1$, first increased from $2.60 \times 10^{7} \mathrm{cfu} / \mathrm{ml}$ at $1.5 \mathrm{~h}$ to $3.10 \times 10^{7}$ $\mathrm{cfu} / \mathrm{ml}$ at $3.5 \mathrm{~h}$, and then decreased to $2.21 \times 10^{7} \mathrm{cfu} / \mathrm{ml}$ at $6 \mathrm{~h}$ when the bacteria proportion was $1: 1: 1$, first increased from $3.31 \times 10^{7} \mathrm{cfu} / \mathrm{ml}$ at $1.5 \mathrm{~h}$ to $7.60 \times 10^{7}$ $\mathrm{cfu} / \mathrm{ml}$ at $4.5 \mathrm{~h}$, and then decreased to $6.70 \times 10^{7} \mathrm{cfu} / \mathrm{ml}$ at $6 \mathrm{~h}$ when the bacteria proportion was $2: 1: 1$, first increased from $4.00 \times 10^{7} \mathrm{cfu} / \mathrm{ml}$ at $1.5 \mathrm{~h}$ to $7.90 \times 10^{7}$ $\mathrm{cfu} / \mathrm{ml}$ at $4.5 \mathrm{~h}$, and then decreased to $6.30 \times 10^{7} \mathrm{cfu} / \mathrm{ml}$ at $6 \mathrm{~h}$ when the bacteria proportion was 3:1:1. Among then, the viable counts of $B$. bifidum at 3:1:1 bacteria proportion reached the maximum $\left(7.90 \times 10^{7} \mathrm{cfu} / \mathrm{mL}\right)$ and followed at $2: 1: 1\left(7.60 \times 10^{7} \mathrm{cfu} / \mathrm{mL}\right)$, the viable counts of $B$. bifidum at 1:1:1 bacteria proportion was the lowest $\left(2.90 \times 10^{7} \mathrm{cfu} / \mathrm{ml}\right)$ at $4.5 \mathrm{~h}$.

Figure $2 \mathrm{~b}$ showed the viable counts of $L$. casei in all BC-goat yoghurt samples first increased within $4.5 \mathrm{~h}$, and then decreased between $4.5 \mathrm{~h}$ and $6.0 \mathrm{~h}$. The viable counts of $L$. casei increased slowly to reach maximum at $4.5 \mathrm{~h}$. Among them, the viable counts of $L$. case $i$ at 2:1:1 bacteria proportion reached the maximum $\left(5.60 \times 10^{7} \mathrm{cfu} / \mathrm{mL}\right)$, the viable counts of $L$. case $i$ at 1:1:1 bacteria proportion was the lowest $\left(3.90 \times 10^{7}\right.$ $\mathrm{cfu} / \mathrm{ml})$ at $4.5 \mathrm{~h}$.

Figure $2 \mathrm{c}$ showed the total viable counts in $\mathrm{BC}$ -goat yoghurt were all first increased then decreased

Table 2. Sensory evaluation of BC-goat yoghurt fermented by different bacteria proportion

\begin{tabular}{cccccc}
\hline $\begin{array}{c}\text { Bacteria } \\
\text { proportion of } \\
\text { BB:LC:LB + ST }\end{array}$ & Colour & Smell & Taste & Texture & $\begin{array}{c}\text { Comprehensive } \\
\text { evaluation }\end{array}$ \\
\hline $1: 3: 1$ & 1.00 & 2.26 & 1.87 & 2.40 & 7.53 \\
$1: 2: 1$ & 1.00 & 2.29 & 1.97 & 2.41 & 7.67 \\
$1: 1: 1$ & 1.00 & 2.36 & 1.97 & 2.40 & 7.73 \\
$2: 1: 1$ & 1.00 & 2.40 & 1.98 & 2.43 & 7.81 \\
$3: 1: 1$ & 1.00 & 2.44 & 1.92 & 2.37 & 7.73 \\
\hline
\end{tabular}


Shu, G., Wang, S., Chen, Z., Chen, H., Wang, C., Ma, Y. (2015). Effect of bacteria proportion on the fermentation of goat yoghurt with probiotic culture. Acta Sci. Pol. Technol. Aliment., 14(4), 407-414. DOI: 10.17306/J.AFS.2015.4.40
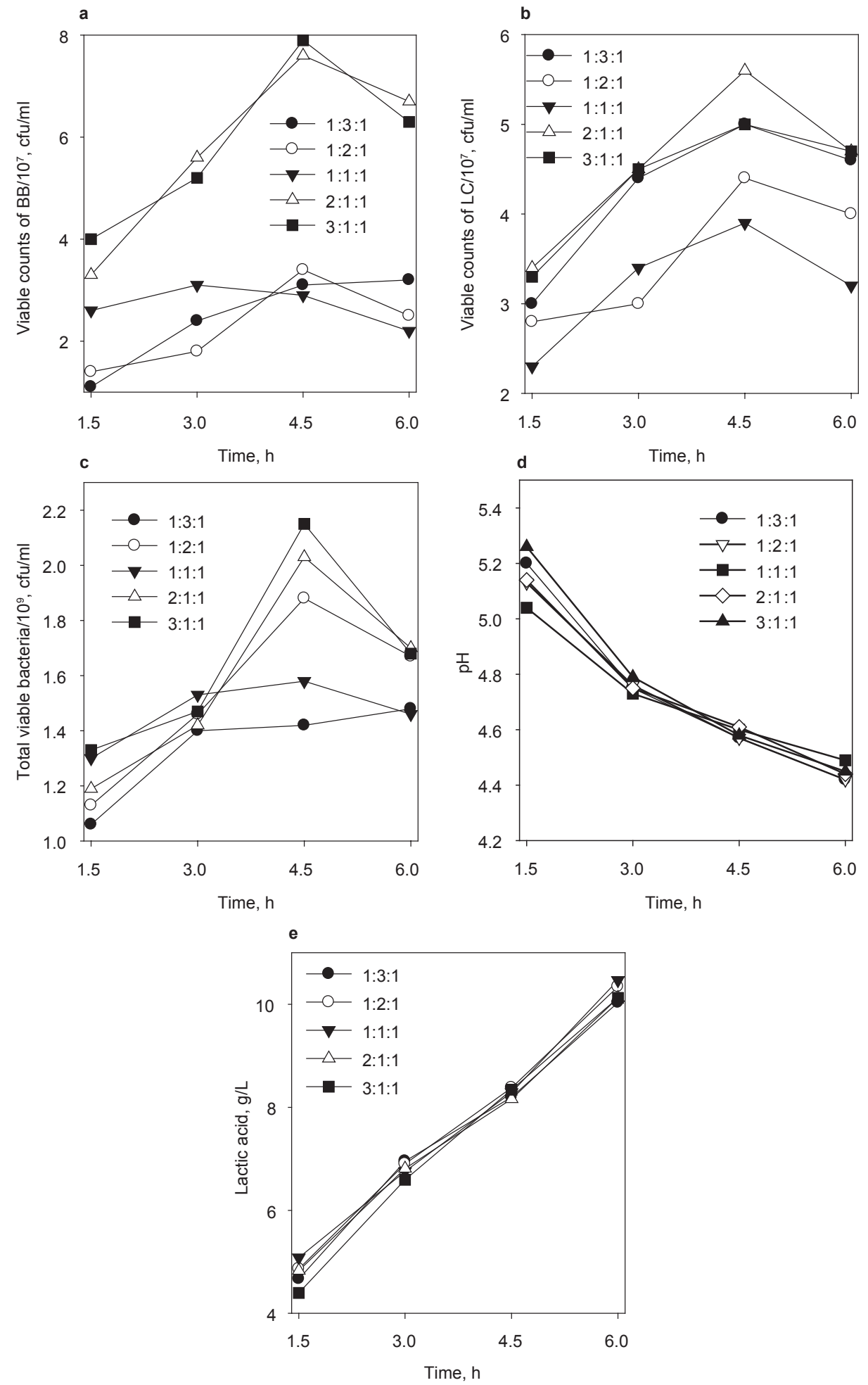

Fig. 2. Effect of bacteria proportion on viable counts of B. bifidum and L. casei, total viable bacteria, $\mathrm{pH}$ and acidity in $\mathrm{BC}$-goat yoghurt 
Shu, G., Wang, S., Chen, Z., Chen, H., Wang, C., Ma, Y. (2015). Effect of bacteria proportion on the fermentation of goat yoghurt with probiotic culture. Acta Sci. Pol. Technol. Aliment., 14(4), 407-414. DOI: 10.17306/J.AFS.2015.4.40

except at 1:3:1 bacteria proportion with time increasing. Among them, the total viable counts at 3:1:1 bacteria proportion reached the maximum $\left(2.15 \times 10^{9} \mathrm{cfu} /\right.$ $\mathrm{mL})$ followed at $2: 1: 1\left(2.04 \times 10^{9} \mathrm{cfu} / \mathrm{mL}\right)$, the total viable counts at 1:3:1 bacteria proportion was the minimum $\left(1.42 \times 10^{9} \mathrm{cfu} / \mathrm{mL}\right)$ at $4.5 \mathrm{~h}$. From Figure $2 \mathrm{~d}$ and $1 \mathrm{e}$, the $\mathrm{pH}$ decreased and the acidity increased in all $\mathrm{AB}$-goat yoghurt. The bacteria proportion had no significant influence on acidity and $\mathrm{pH}(p<0.05)$.

Table 2 showed the bacteria proportion had no significant influence on the colour, taste and texture of BC-goat yoghurt $(p>0.05)$, however, had a significant effect on odour. The BC-goat yoghurt had obvious goaty flavour at $1: 2: 1$ and $1: 3: 1$, but had slight goaty flavour at 1:1:1, 2:1:1, 3:1:1; the comprehensive evaluation at 2:1:1 bacteria proportion was better than the other.

According to the analysis and discussion of the above, the optimum bacteria proportion of B. bifidum : L. casei : S. thermophilus and L. bulgaricus for BC-goat yoghurt was 2:1:1.

\section{CONCLUSIONS}

The bacteria proportion had a significant effect on fermentation of AB- and BC-goat yoghurt. The optimum bacteria proportion for $\mathrm{AB}$-goat yoghurt and $\mathrm{BC}$-goat yoghurt were both 2:1:1. The $\mathrm{pH}$, acidity, the viable counts of $L$. acidophilus and B. bifidum, the total viable counts were respectively 4.60, $7.73(\mathrm{~g} / \mathrm{L})$, $3.50 \times 10^{7} \mathrm{cfu} / \mathrm{mL}, 3.40 \times 10^{7} \mathrm{cfu} / \mathrm{mL}$ and $2.30 \times 10^{9} \mathrm{cfu} /$ $\mathrm{mL}$ in $\mathrm{AB}$-goat yoghurt. The $\mathrm{pH}$, acidity, the viable counts of B. bifidum and $L$. casei, the total viable counts were respectively $4.61,8.16(\mathrm{~g} / \mathrm{L}), 7.60 \times 10^{7}$ $\mathrm{cfu} / \mathrm{mL}, 5.60 \times 10^{7} \mathrm{cfu} / \mathrm{mL}$ and $2.04 \times 10^{9} \mathrm{cfu} / \mathrm{mL}$ in BCgoat yoghurt.

\section{ACKNOWLEDGEMENT}

The project was partly supported by the Science and Technology Research Development plan project of Shaanxi Province, China (No. 2014K01-17-07), the Scientific Research Program Funded by Shaanxi Provincial Education Department (No. 2013JK0747) and the science and technology plan project of Xi'an city [No. NC1317 (1)].

\section{REFERENCES}

Boycheva, S., Dimitrov, T., Naydenova, N., Mihaylova, G. (2011). Quality characteristics of yoghurt from goat's milk, supplemented with fruit juice. Czech J. Food Sci., 29, 1, 24-30.

Chen, H., Wang, C., Shu, G. (2010). Technological optimization of set-style goat yoghurt fermentation. Sci. Techn. Food Ind., 35, 12, 71-74.

Chen, H., Ji, L., Shu, G., Wang, Z. (2011). Effect of lithium chloride and sodium propionate on growth of selected probiotics. Key Eng. Mater., 480/481, 66-69.

Chen, H., Zhang, Q., Wan, H., Shu, G., Li, H. (2015). Effect of total inoculum size containing Lactobacillus acidophilus or Lactobacillus casei on fermentation of goat milk. Adv. J. Food Sci. Techn., 7, 3, 183-186.

Farnsworth, J. P., Li, J., Hendricks, G. M., Guo, M. R. (2006). Effects of transglutaminase treatment on functional properties and probiotic culture survivability of goat milk yoghurt. Small Ruminant Res., 65, 1, 113-121.

Haenlein, G. F. W. (2004). Goat milk in human nutrition. Small Ruminant Res., 51, 2, 155-163.

Kailasapathy, K., Chin, J. (2000). Survival and therapeutic potential of probiotic organisms with reference to Lactobacillus acidophilus and Bifidobacterium spp. Immunol. Cell Biol., 78, 1, 80-88.

Krasaekoopt, W., Bhandari, B., Deeth, H. (2003). Evaluation of encapsulation techniques of probiotics for yoghurt. Int. Dairy J., 13, 1, 3-13.

Mutlu, B. G., Akın, S. M. (2007). Effects of cysteine and different incubation temperatures on the microflora, chemical composition and sensory characteristics of bio-yoghurt made from goat's milk. Food Chem., 100, 2, 788-793

Park, Y. W. (1994). Hypo-allergenic and therapeutic significance of goat milk. Small Ruminant Res., 14, 2, 151-159.

Posecion, N. C., Crowe, N. L., Robinson, A. R., Asiedu, S. A. (2005). The development of a goat's milk yoghurt. J. Sci. Food Agric., 85, 11, 1909-1913.

Rolfe, R. D. (2000). The role of probiotic cultures in the control of gastrointestinal health. J. Nutr., 130, 2, 396-402.

Shu, G., Ma, Z., Wang, Z., Chen, H. (2011). Effect of bile and nalidixic acid on growth of selected probiotics. Adv. Mat. Res., 322, 248-251.

Shu, G., Li, C., Chen, H., Wang, C. (2014). Effect of inoculum and temperature on the fermentation of goat yoghurt. Adv. J. Food Sci. Techn., 6, 1, 68-71. 
Shu, G., Wang, S., Chen, Z., Chen, H., Wang, C., Ma, Y. (2015). Effect of bacteria proportion on the fermentation of goat yoghurt with probiotic culture. Acta Sci. Pol. Technol. Aliment., 14(4), 407-414. DOI: 10.17306/J.AFS.2015.4.40

Singh, K., Kallali, B., Kumar, A., Thaker, V. (2011). Probiotics: A review. Asian Pac. J. Tropic. Biomed. 2, 1, S287-S290.

Received - Przyjęto: 9.04.2015

Shu, G., Wang, S., Chen, Z., Chen, H., Wang, C., Ma, Y. (2015). Effect of bacteria proportion on the fermentation of goat yoghurt with probiotic culture. Acta Sci. Pol. Technol. Aliment., 14(4), 407-414. DOI: 10.17306/J.AFS.2015.4.40
Uysal-Pala, C., Karagul-Yuceer, Y., Pala, A., Savas, T. (2006). Sensory properties of drinkable yoghurt made from milk of different goat breeds. J. Sens. Stud., 21, 5, $520-533$.

Accepted for print - Zaakceptowano do druku: 25.07.2015

\section{For citation - Do cytowania}

